\title{
The Future of Communal Lands in Africa: Experiences from Namibia
}

\author{
Romie Vonkie Nghitevelekwa
}

\section{$1 \quad$ Introduction}

The large-scale land losses of small-scale farmers are characteristic of subSaharan Africa and have had a significant impact on the rural economies of the region (Wily 2012: 751). For countries like Namibia and other former settler colonies, these land losses, or dispossessions as they are known, can be traced back to the colonial period, where they formed a key component of the colonial political economy. First, this resulted in a blatantly unequal distribution of land, with which countries like Namibia and South Africa continue to grapple. Second, colonial land policies created a dual land tenure system, which forced rural dwellers into one of two tenure forms along racial lines. African populations were to subsist on communal land, whereas the white settlers in the freehold land areas established a market economy. During the different epochs of colonialism and apartheid, communal land has undergone what Wolfgang Werner calls administrative incarnations (Werner 2015). The German colonial administration initially set up native reserves, while the South African apartheid administration established first homelands and, later, communal lands. The traditional authorities, working in close conjunction with a white dominated administration, were made responsible for managing the reserves and later homelands and/or communal land. After independence in 1990, the Namibian government retained the dual land tenure system of both communal and freehold land. The administration of communal land remained in the hands of the traditional authorities, a function that was given legal effect with the passing and enactment of the Communal Land Reform Act in 2002 (Republic of Namibia 20O2).

What are the future prospects of communal land? At present, it is seen either as a safety net for the rural poor, or as a resource for commercial exploitation (Dobler 2013). Each of these conflicting uses not only serves the interests of different groups, but also produces different visions of land rights and envisions different futures (Nghitevelekwa 2O2O) and, it is these futures that I aim to untangle.

(C) ROMIE VONKIE NGHITEVELEKWA, 2022 | DOI:10.1163/9789004471641_013 
In pre-colonial Namibia, land tenure and land use were organized communally, albeit in a number of different ways. Southern Namibia, for example, where the people led pastoral lives, was characterized by a "high degree of mobility" and, although the authorities were aware of the markers of the areas under their respective jurisdictions, there were no rigid boundaries. The people in northern Namibia, however, were agro-pastoralists for whom "land was owned by the community as a whole" with individualized landholdings allocated to households on a permanent basis, though certain resources such as pastures were shared (Werner 1993: 137). Land dispossession by the German colonists, which was later consolidated by the South African apartheid regime and the implementation of land policies that introduced rigid boundaries and the system of dual land tenure, drastically changed these systems. The African populations were then confined to areas demarcated as reserves (later called homelands and then communal lands), which served the important function of providing cheap labour to the colonial market economy. For instance, by 1913 an estimated 12,500 male Africans were working on the farms and about 10,000 in the larger mining and government enterprises in the police zone. Contract labourers fuelled the colonial economy, but at the expense of the communal land areas (Melber 2010). In northern Namibia (Owambo), for example, the loss of strong young men to migrant labour (Haahti 1912 in Melber 2010: 39) seriously undermined traditional modes of production and social structures. While the arable lands were shrinking and producing fewer yields, the wages earned from the colonial economy were too low to sustain people's livelihoods in the communal areas (Melber 2010; also see Likuwa 2020).

Following the recommendations of the Odendaal Commission, which proposed an "amalgamation and expansion of some of the reserves" (Werner 1993: 145), the term 'reserves' was changed to 'ethnic homelands'. Then, from the 1980 on onwards, legislation was passed that stipulated that 'ethnic homelands' were to be renamed 'communal lands'. One of the key legislations was the Representative Authorities Amendment Proclamation AG 4, in particular its Section 4, which vested the trusteeship of communal land to the administrator-general (Amoo 2014). Following independence, all colonial land policies and laws were repealed; trusteeship of communal land was then transferred to the independent Namibian state and the traditional authorities were made responsible for its administration. 


\section{Communal Lands and Early Penetration of Market-Exchange Relations}

Despite domination by the colonial administration and indirect rule, monetary exchange relations did not fully penetrate the communal land areas. Although their pay packets were pathetically low, migrant labourers brought a cash-based economy into the communal areas, albeit, as Wolpe (1972) argues for South Africa, in highly unequal ways. To enable cheap reproduction and to prevent the emergence of a landless proletariat, the land was not commodified, but labour was. In addition, and also linked to labour migration, monetary exchange relations penetrated the communal land areas through the illegal trade in diamonds, although this was often under cover (Amupanda 2020).

Even before the start of the twentieth century, a form of petty trade was already in existence in which missionaries bartered European goods in exchange for such things as cattle, ivory, and ostrich feathers. Although earlier attempts were made to open trading stores in north-central Namibia, the first one did not materialize until 1925 and its existence was closely linked to labour migration (Dobler 2014). The spending power of labour migrants had opened up avenues for monetary exchange in communal areas, but these did not extend to land transactions. Moreover, land speculation remained absent from communal areas where land could be neither bought nor sold, and commercial leasing was out of the question. The productivity of the land remained largely oriented towards ensuring the basic subsistence needs of the resident population. In fact, the Namibian communal land areas were what I refer to as 'last frontiers'. These were the places where people continued to eke out a living; they were the safety nets for the poor.

Post-Independence Developments and the Scramble for the 'Last Frontiers'

The marginalized, underdeveloped 'homelands' were established to be just that, namely labour reserves and places in which to keep the so-called nonproductive social groups - the elderly, the children, the women, and the sick. Today's communal land areas now face the threat of appropriation by the highest bidder. In 2002, 12 years after attaining independence, Namibia enacted a law on communal land - the Communal Land Reform Act - and this kickstarted the communal land reform process. Through communal land reform, different kinds of land rights are registered and legally secured. Three kinds 
(customary, leasehold, and occupational land rights) cater for the different forms of land use now found on communal land. Customary land rights are granted for farming and residential use, and their statutory protection is particularly important in the context of high competition. Leasehold rights are granted for general business and commercially oriented agricultural purposes, while occupational land rights are granted for public bodies such as educational and health institutions.

James Ferguson correctly observes that for southern Africa "the importance of land, and the desire for it, seems in some ways to loom as large as ever" (Ferguson 2013: 167). In Namibia, competition for land is fierce. There is, however, less communal than freehold land available (38 per cent as opposed to 48 per cent of the total land area respectively). Speculation in the communal areas, be it for land or for land-based resources such as timber, is now an everyday occurrence (Peters 2020). A variety of different forces and actors, as well as economic and social processes, account for this development. The demand for land as a basic safety net for residents remains. An interest in this land also comes from people living in urban areas as far as 700 kilometres away. Some argue that the members of this group, particularly the wealthier ones, feel that they ought to own farmland - and a substantial amount at that - in their home village as a mark of their status and willingness to maintain links with their place of origin (Schnegg et al. 2013). It is impossible to undervalue the relationship between land, a sense of belonging, and social identity. Most urban dwellers do not regard the urban areas in which they live as home. On the contrary, home is the rural village; it is where they are expected to own land, although some use their power to amass large tracts at the expense of other communal land users.

The increased demand for communal land has driven market exchange transactions that are illegal because the communal land legislation prohibits them (Mendelsohn and Nghitevelekwa 2016). Moreover, the desire for communal land derives from a wish to invest not only in large-scale market-oriented cash-crop production and cattle herding, but also in tourism and the hospitality industry and, in the process, to use foreign investors and their national partners. By entering into concession agreements with community-based institutions, like conservancies, more established tourism and hospitality businesses can benefit from the best kept natural environments and cultural endowments on communal land and develop them into highly valuable tourism enterprises. There are other economically and developmentally-driven interests in the land. For instance, the alienation of communal land for the establishment or expansion of townlands is widespread. Townlands in northern Namibia are mushrooming in once rural and communal areas. With the 
cooperation of the Ministry of Rural and Urban Development, town councils can turn these lands into townlands. According to the Communal Land Reform Act (2002), once an area has been declared a townland, it ceases to be communal land and, in terms of governance and administration, shifts from the jurisdiction of the traditional authorities to that of the town councils. In these various ways, communal land is being commodified (Lenggenhager et al. 2021).

Unlike the scramble for Africa in the late nineteenth century (Carmody 2011), today's scramble is for the 'last frontiers' - the public land, or edu laaveshe (land for all), as local land users in north-central Namibia's communal areas refer to it - that has remained in the hands of the poor. Natural resources (be they mineral or marine-based) have, through the processes of exploitation and underdevelopment, been exported to faraway lands. The old players remain, but new players seek new ground for the extraction and exploitation of land and land-based resources. Indeed, Africa's 'last frontiers' are playing fields for global and local investors. Different players toss dominoes as they compete to influence social networks to assert their interests. Biofuels and minerals (iron, cobalt) have gained significance and prominence (AUC-ECA-AfDB Consortium 2010). Lucrative licences for wildlife, oil exploration, fisheries (see the Fishrot scandal) have been granted to international 'investors'. In Namibia, the growing demand for timber and tobacco for the Asian economies has also become apparent. Areas such as the Kavango, diverse in biological diversity and with a good track record in conservation, are now open to oil exploration by Canadian investors. In short, communal land areas are being progressively integrated into market relations (Nghitevelekwa 2020).

\section{5}

\section{The Dynamics of Land Commodification: Who is Benefiting?}

The dynamics and compulsions behind the commodification of Namibia's communal land areas are driven by more than the demand of hungry Asian economies for cheap raw materials. The need to eradicate poverty and other social ills, such as high levels of unemployment, is also used to justify the foreign direct investments. There is a wide consensus that economic progress and poverty alleviation can only be achieved within the context of a marketoriented economy. According to this view, selling the labour force, land and other natural resources, and creating a market for them, is fundamental to alleviating poverty. The preoccupation with what Ian Hacking (1982, cited in Appadurai 2013: 295) called "the avalanche of numbers about population, poverty, profit, and predation", produces economic initiatives that are often 
approved and implemented at any cost. It is often not asked who these investments and developments are meant to serve and how useful they are to the lives of the target population.

Since independence, Namibia's economy has grown considerably, from US\$ 2.804 billion in 199 o to US $\$ 12.37$ billion in 2019, although it was expected to record a 7.3 per cent contraction in 2020 because of the devastating impact of the Covid-19 pandemic (Bank of Namibia 2020). Although this growth has enabled the country to graduate to the status of upper middle-income country, it has failed to address the social ills that the country is facing. Unemployment and poverty rates remain high at 33.4 per cent and 26.9 per cent respectively (Namibia Statistics Agency 2018, 2019). Unemployment and poverty are most pronounced in the rural, and thus communal, land areas. Hence, these social ills are used as justification for much needed 'investment' and 'development'. There is a need to interrogate the diverse implications of market penetration. Central to this interrogation should be the question of whether the local population will be able to participate actively and benefit from a market-driven rural economy, or will the people continue to be reduced to mere spectators. This conundrum is questioned in the following two examples.

In 2019, the Namibian Cabinet approved the development of a Namibia Oriental Tobacco cc project in the Zambezi Region, where climate and soil conditions are better than elsewhere in the country. The company had applied for a 99-year lease to grow tobacco on 10,00o hectares of communal land (Tjitemisa 2019) to be developed by a Chinese investor with a local partner. It is unclear how the general populace in the area will benefit. How substantial and meaningful will these benefits be? To what extent will the project eradicate poverty or reduce unemployment? What kinds of employment will it create? Will it just generate a working poor as many of these kinds of projects do? Are these kinds of projects turning those who have long lived on and off the land into a landless proletariat, or force them to squat with relatives in neighbouring communities? While these kinds of initiatives are approved and supported in the name of 'investment' and the 'free market', in practice, can they be construed to be nothing but the classical extraction of Africa's raw materials for further processing in the destination zones? One is further left with an important question: what kind of mechanisms would need to be in place to prevent or end unwanted consequences and which ones could ensure the equitable sharing of revenues and environmental sustainability?

Asian companies, particularly Chinese and Vietnamese ones, have found a new niche in Namibia, namely forest logging. For the past three or so years, truckloads of timber - including precious rosewood - have been travelling along the Trans-Kalahari Highway to and from northeastern Namibia (some 
also from landlocked Zambia, which relies on Namibia for access to the coast) to the port of Walvis Bay. The Ministry of Agriculture, Water and Land Reform and the Ministry of the Environment, Forestry and Tourism, the two government bodies responsible for safeguarding Namibia's environment, have received numerous requests from the public to put a stop to this illegal logging of timber (The Namibian 2019). According to the Ministry of Agriculture, Water and Forestry, in the first two months of 2019, about 75,000 tons of timber were exported from Namibia, at an estimated value of N\$94 million (Brandt 2019). Because of the high consumer demand in China for dark red tropical hardwood species, the Chinese market is a big importer of rosewood - the main tree species logged. Key to the logging and exploitation of timber are questions of environmental sustainability and of how, given that these trees are felled in communal land, the communities have benefited. How much of the revenue trickles down to the people living in the areas where the timber has been logged? While timber logging does not compete for space with smallholders, it nonetheless creates environmental problems in terms of deforestation and biodiversity loss, which is also a loss for communities already affected by climate change. The timber products are extracted from rural and communal areas where poverty is rife, but most of the profits derived from them go to commercial companies abroad. Whereas some cash remains with the local partners or authorities, there is a lack of transparency and of democratic control over it.

\section{6} Conclusion: How Can Local Populations Benefit?

When looking at the future, Arjun Appadurai (2013) detects a tension between the ethics of possibility and of probability. The ethics of possibility encompasses views on "thinking, feeling, and acting that increase the horizon of hope, that expand the field of imagination, that produce greater equity ... in the capacity to aspire, and that widen the field of informed, creative, and critical citizenship" (Appadurai 2013: 295). The ethics of probability, by contrast, encompasses ideas on "thinking, feeling, and acting that flow out of what Ian Hacking called 'the avalanche of numbers' or what Michel Foucault [1979] saw as the capillary dangers of modern regimes of diagnosis, counting, and accounting" (Appadurai 2013: 295). In this context, the probability is that, if left to run its course, the penetration of markets will have disastrous implications for most of the rural population; it will exacerbate existing inequalities and, in the event of uncontrolled timber logging, will also have catastrophic effects on the environment. The possibility, on the other hand, lies in the prospect of ongoing tenure reform 
programmes successfully offering statutory protection to customary land rights in communal areas. The tenure reform that is currently ongoing in most African countries - and in Namibia through the communal land reform programme "is offering Africa an unexpected opportunity to move into a more inclusive and equitable era of social transformation through decolonizing property rights" (Wily 2020: 57). While legal recognition and protection has been extended to customary land rights, the hope should lie in the possibility of recognition and protection also preventing appropriation. So far, however, "legal recognition has not prevented appropriation" (Peters 2020: 80). If we allow the highest bidder to capture the communal land at the expense of the rural poor, we jeopardize our ability to look at the future with aspiration, anticipation, and imagination (Appadurai 2013: 286). Today's tenure reform should be sufficiently transformative to secure communal land users' rights against appropriation and to include those who inhabit communal land as veritable partners in development, and not as mere spectators as their long-held resources are exploited by others through capitalism. Surely, communal land should not be excluded from the process of maximizing its potential. However, the current legal framework is inadequate to the task of ensuring that this is done in an inclusive and equitable manner. Better regulations should be introduced to strengthen protection and to allow for a fairer distribution of benefits from the commercial use of communal land.

\section{References}

Amoo, S. 2014. Property law in Namibia. Pretoria: University of Pretoria Press.

Amupanda, J. 2020. The consolidated diamond mines the natives in colonial Namibia: A critical analysis of the role of illegal diamonds in the development of Owamboland (1908-1990). PhD thesis, University of Namibia.

Appadurai, A. 2013. The future as a cultural fact: Essays on the global condition. London: Verso.

AUC-ECA-AfDB Consortium. 2010. Framework and guidelines on land policy in Africa: Land policy in Africa: A framework to strengthen land rights, enhance productivity and secure livelihoods. AUC-ECA-AfDB Consortium.

Bank of Namibia. 2020. Economic outlook update. Windhoek: Bank of Namibia.

Brandt, E. 2019. "N\$94m worth of timber exported in first two months of 2019 ... No policy for timber harvesters to plant trees." New Era Newspaper, Namibia, 17 June.

Carmody, P. 2011. The new scramble for Africa. Cambridge: Polity Press.

Dobler, G. 2013. Communal land reform in Namibia: History, practices and future challenges. Cape Town, South Africa. 
Dobler, G. 2014. Traders and trade in colonial Ovamboland. Basel: Basler Afrika Bibliographien.

Ferguson, J. 2013. "How to do things with land: A distributive perspective on rural livelihoods in southern Africa." Journal of Agrarian Change, 13, 1: 166-174.

Hacking., I. 1982. "Biopower and the avalanche of printed numbers." Humanities in Society, 5: 279-295

Lenggenhager, L., L. Bloemertz and R. Nghitevelekwa. 2021. "Turning Land Into Capital: Ineqaulity and Reforms in Namibia." Review of Agrarian Studies, 11, no1: 3-21.

Likuwa, K. 2020. Voices from the Kavango. A study of the contract labour system in Namibia, 1925-1972. Basel: Basler Afrika Bibliographien.

Melber, H. 2010. "Economic and social transformation in the process of colonisation: Society and state before and during the German rule." In State, society and democracy: A reader in Namibian politics, edited by C. Keulder, 16-48. Windhoek: Macmillan Education Namibia.

Mendelsohn, J. and R. Nghitevelekwa. 2016. "A study of land markets in Namibia's communal areas." Consultancy report. Windhoek: Ministry of Land Reform.

Namibia Statistics Agency. 2018. Namibia household income and expenditure survey 2015/2016 report. Windhoek: Namibia Statistics Agency.

Namibia Statistics Agency. 2019. The Namibia labour force survey 2018 report. Windhoek: Namibia Statistics Agency.

Nghitevelekwa, R. 2020. Securing land rights: Communal land reform in Namibia. Windhoek, Namibia: University of Namibia Press.

Peters, P. E. 2020. “The significance of descent-based 'customary' land management for land reform and agricultural futures in Africa." In Rethinking land reform in Africa: New ideas, opportunities and challenges, edited by African Development Bank, 70-82. Abidjan: African Development Bank.

Republic of Namibia. 2002. Communal land reform act, Pub. L. No. 05.

Schnegg, M., J. Pauli and C. Greiner. 2013. "Pastoral belonging: Causes and consequences of part-time pastoralism in Northwestern Namibia." In The emergence, history and contemporary political ecology of African pastoralism, edited by M. Bollig, M. Schnegg and H. P. Wotzka, 341-362. Oxford: Berghahn.

The Namibian. 2019. "Anger over illegal timber harvesting." The Namibian, 13 May.

Tjitemisa, K. 2019. "Cabinet approves Zambezi tobacco plantation." New Era, 14 June.

Werner, W. 1993. "A brief history of land dispossession in Namibia." Journal of Southern African Studies, 19, 1: 135-146.

Werner, W. 2015. "Tenure reform in Namibia's communal areas." Journal of Namibian Studies, 18: 67-87.

Wily, L. A. 2012. "Looking back to see forward: The legal niceties of land theft in land rushes." The Journal of Peasant Studies, 39, 3/4: 751-775. 
Wily, L. A. 2020. "Adjusting to new era agrarianism: Tackling the Troubled interface of public and community property." In Rethinking land reform in Africa: New ideas, opportunities and challenges, edited by African Development Bank, 57-69. Abidjan: African Development Bank.

Wolpe, H. 1972. "Capitalism and cheap labour-power in South Africa: From segregation to apartheid." Economy and Society, 1, 4: 425-456. 